\title{
Empirical Study Impact of Emotional Intelligence on Organizational Development Some Selected Public Service Organizations in Dire Dawa, Ethiopia
}

\author{
BINIYAM KEBEDE DESTA \\ Lecturer of Management, College of Business (Department Head of MBA) \\ Addis Ababa Medical and Business College in Dire Dawa, Ethiopia
}

\begin{abstract}
This research article focuses on the influence of emotional intelligence on organizational development. It also considers the relationship between age, gender, educational qualification and experience of employees and the EI factors. The EI factors such as empathy, self-awareness, self-regulation, social skills and motivation and OD techniques like sensitivity training, process consultation, team building, organization process building, HRM and strategic interventions are considered for the purpose of the study. In this research paper, the relationship between EI factors and OD interventional strategies is analyzed in detail by using multiple correlation and factor analysis. Based on the research analysis, appropriate strategies are suggested for improving the emotional intelligence of the work force.
\end{abstract}

Keywords: Emotional Intelligence, Empathy, Organizational Development, Process Consultation, Sensitivity Training and Team Building.

DOI: $10.7176 /$ PPAR/10-4-01

Publication date: April $30^{\text {th }} 2020$

\section{INTRODUCTION}

\subsection{Background}

Public sector organizations expect their employees to effectively communicate and convey information, to interpret others' emotions, to be open to others' feelings, to solve conflicts and arrive at resolutions. By acquiring these skills, the employees and those in management positions can lead others to improve their efficiency and thereby to enhance the productivity of human capital. Controlling emotions is essential for good decision-making and to preserve harmony around us. We admire people who have the ability to control their emotions when they face pressure, arguments and aggression. We also enjoy being with people who can express empathy, compassion, cooperation and forgiveness.

Emotional Intelligence Quotient is the innate potential to feel, use, communicate, recognize, remember, learn from, manage and understand others' emotions. Emotional sensitivity; Emotional memory; Emotional processing ability and Emotional learning ability, the major activity problems at work are caused by unmet emotional needs. The emotionally intelligent manager knows how to identify and manage the emotional needs of both the customers and his team. They wants to help other feel respected, acknowledged, supported, helped, trusted, appreciated, important, special, irreplaceable, useful, needed and valued. When our emotional needs are satisfied we feel better, and when we feel better we are more productive, motivated, patient, creative, cooperative, open-minded, flexible, understanding, caring, empathic and compassionate.

High levels of emotional intelligence are associated with better performance in the following areas: participative management, putting people at ease, self-awareness, balance between personal life and work, straight forwardness and composure, building and mending relationships, doing whatever it takes, decisiveness and confronting problem employees.

Goleman (1995) has defined emotional intelligence as "the abilities such as being able to motivate oneself and persist in the face of frustrations; to control impulse and delay gratification; to regulate one's moods and keep distress from swamping the ability to think; and to emphasize and to hope." In 1998, Goleman refined the definition of emotional intelligence to "the capacity for organizing our own feelings and those of others, for motivating ourselves, and for managing emotion well in ourselves and in our relationships" (Goleman, 1998). He applied EI as a concept in the workplace setting. Goleman presents emotional intelligence as a skill with two key areas in his emotional competence framework; "personal competence" which represents how to manage ourselves (i.e. selfregulation, self-motivation, etc.) and "social competence" which represents how to manage relationships (i.e. empathy, and social skills) (Goleman, 1995). Knowing owns capacity knowledge, weakness and strength, competency gaps, feelings (self-awareness); having the mechanisms to control owns emotions (self-control); knowing about the society, (social skills); having the knowledge of managing the social relationship (relationship management skill) will make any person to be he/she is emotionally intelligent.

The organizations must coach their employees in developing their interpersonal skills and coach them to perform effectively on the job with other employees in the organization (Bar-On et al, 2007). Organizations to be 
successful need to develop employee's emotional intelligence skills to work effectively in the organization (Wall, 2008).

The efficient and quality services are not the result of a single causal factor; it is a result of the multiple factors. According to Naeem et al. (2008) human effort an emotional intelligence are more important determinants of service quality. Public organizations as the service providers are required to be adaptive towards the demands and behaviors of the customers, it is basically emotional intelligence that helps managers in responding effectively towards the customer needs. The learning and practice of these skills help to improve the performance of service providers and thus to increase customer satisfaction. By using emotional intelligence, organizations can have increased knowledge about customers and greater ability for recognizing and regulating the quality of service according to the desires of customers (Naeem et al. 2008).

Organization Development (OD) is the process of improving organizational effectiveness and/or the effectiveness of individual employees. OD Interventions are the sets of structured/planned activities adopted by groups or individuals in an organization as a part of the organization development program. An intervention is a set of sequenced and planned actions or events intended to help the organization increases its effectiveness. Some of the OD interventions include: sensitivity training, process consultation, team building, organizational process building, Human Resource Management interventions and strategic interventions.

Studies found that emotions of an employee's make a huge gap in organizational success and organization development. Public organizations needs emotionally intelligent employees because the task is complex and organized for service delivering for peoples. Due to the above mentioned and other benefits of the emotion of employees the researcher interested to study on the Public sector organizations in Dire Dawa Administration, Ethiopia. The researcher's current working experience and working environment the public sector organizations will be the best area to show the impact of emotional intelligence on organizational development, because some selected public sector organizations is huge area having communication with different parts of the society at daily base and it needs team work for the success of an organization. Employees in some selected public sector organizations have a direct link on emotional intelligence since the employees have to deal with different customers who have different level of emotions face to face. Studies done in different part of the world shows that there is positive relationship between emotional intelligence of employees on their organizational successes, For example: Goleman, et al., (2002) has reported that EI is positively related to a person's leadership quality, performance, and effectiveness. Other evidence has suggested that EI is essential for effective performance (Cooper \& Sawaf, 1998; Druskat \& Wolff, 2001; Salovey \& Shiyter, 1997). George \& Brief, (1996), have theorized that job performance is influenced by the employees' ability to use emotions to facilitate performance.

The major problems at work are caused by unmet emotional needs. The emotionally intelligent manager knows how to identify and manage the emotional needs of his team. High levels of emotional intelligence are associated with higher productivity and organizational development. Hence, there is a need to understand the influence of emotional factors on organization growth and development.

The review of related literature in the area of emotional intelligence and its impact on work performance spanned for more than three decades and provided the researcher valuable inputs, perspective, insights and direction in understanding these factors and designing this study.

Thus, there is a need to fulfill a knowledge gap in this field. The researcher does not measure emotional intelligence of individuals, their attitude towards others at work in an organization or how good the organization is in developing people for the work environment; but rather it tries to find out the relationship between the factors of intelligence and factors of organizational development and thereby deriving a relationship between the two in Dire Dawa Administration, Ethiopia.

\subsection{Objectives of the study}

1. To study the impact of emotional intelligence of employees on organizational development.

2. To ascertain the relationship between age, gender, educational qualification and experience of employees and the EQ factors.

3. To find out the relationship between EQ factors and OD interventional strategies.

\subsection{Significance of the study}

The Public sector organizations competent workforce if they want possesses distinctive competencies in this highly competitive business world. The findings will be important for the Public sector organizations to give more emphasis on emotional intelligence of their employees to be successful and achieve their organizational vision and that brings to for the contribution of people's skills in service delivery. Secondly, the findings of this study will be useful, as contribution to literature on emotional intelligence in a different context.

\subsection{Limitations of the Study}

- The findings of the study are based on the views of only 150 sample respondents. Hence, they are to be 
carefully considered for generalization.

- The inferences drawn are subjected to bias and prejudice of the respondents.

- The accuracy of findings is limited by the accuracy of data collected and statistical tools used for analysis.

- The findings are constrained by sampling and non-sampling errors.

\section{LITERATURE REVIEW}

\subsection{Emotional Intelligence}

Firstly the concept of emotional intelligence was introduced by Salovey and Mayer in 1990. Emotional intelligence is an ability of monitoring and discriminating the emotions of one's own and others for the purpose of use information to guide thinking and action. Zhou and George (2003) explained the emotional intelligence as a leadership quality which promotes and enables follower's creativity, leaders with higher level of emotional intelligence have ability to encourage, support and awaken creativity between the employees of an organization. Similarly employees with higher level of emotional intelligence abilities have greater chance to gain success than the people with lower level of emotional intelligence competencies (Anari, 2012).

EI has gain intensive attention of researchers from different fields. Concept of EI is derived from the concept of social intelligence which was described by Thorndike in 1920, who defined social intelligence "the ability to understand and manage men and women, boys and girls to act wisely in human relation. "Number of scholars has proposed many definitions of this concept, Wong and Law described four components of EI: self-emotion appraisal, others emotion appraisal, regulation of emotion and use of emotion (Law et al., 2004; Wong and Law, 2002).

Other scholars, including Bar On (1997) and Goleman (1995), have derived alternative models of EI; these models define in the sense of personality factors and traits (assertiveness and motivation). Mayer and Salovey criticized to the trait model and argued that talent and trait must be separate from EI. Trait is a characteristic of personality or way of behaving whereas talent can be defined as a nonintellectual ability. Mayer et al., $(1999,2004)$ suggested a mix model. These all model have a lot of critics, For example overlapping in measures of EI personality trait's measures (Davies et al., 2008). In the view of these responses of criticism validity is established of Mayer and Salovey's model (Ciarrochi et al,. 2000; Mayer, 2001; Mayer et al., 1999, 2004) two scholars invented the concept and defined as "the ability to perceive accurately, appraise, and express emotions; the ability to access and/or generate feelings when they facilitate thought; the ability to understand emotions and emotional knowledge; and the ability to regulate emotions to promote emotional and intellectual growth" (Mayer and Salovey, 1997). Mayer and Salovey (1997) EI concept includes two component, intelligence and emotions psychologist made a three part division of mind (i.e. cognition, affect and motivation) intelligent belong to cognition and emotion belong to affect sphere. Motivation is third part which encourages towards learning goal achieving behavior. In this way ability model focuses on cognitive abilities and emotions.

Gadot and Meisler (2010) argued there is a consensus about emotional intelligence that it is an ability to establish accurate reasoning of emotions, ability to enhance thought through proper utilization of emotions, feelings and emotional knowledge. Gadot and Meisler (2010) emotional intelligence include two concepts (i.e intelligence and emotion) intelligence is relates to the ability to understand information and emotion involves to a coordinated behavior towards environment. Importance of EI in human lives has succeeded to get attention of researcher from different fields. EI plays a very vital role at work arena which forced researcher to explore EI at workplace. For Example, researchers tested the relationship between EI and other employee's work attitudes or behaviors including emotional commitment, job satisfaction and turnover intentions (Carmeli, 2003; Jordan \& Troth, 2011; Vigoda-Gadot \& Meisler, 2010). The emotional intelligence helps employees to get optimistic results when they encounter with a situation of stress (Tsarenko \& Strizhakova, 2013). Emotional intelligence has four components according to Goleman (1995) new model. These are as follows:

\subsection{Models of Emotional Intelligence}

All of the theories and models in conceptualization of EI are under the umbrella of three main lines of thought including: trait approach, ability approach and mixed approach these are the models proposed by Mayer and Salovey, Bar-on and Goleman. Each of their theoretical framework conceptualize emotional intelligence from one of two perspectives: as a form of pure intelligence consisting of mental ability only or as a mixed intelligence consisting of both mental ability and personality characteristics like optimism, adaptability and well-being. Till now, the only ability model of emotional intelligence is that proposed by Mayer and Salovey, they considered EI as a form of pure intelligence consisting of cognitive ability only. The two mixed models distinguish from each other; the differences in which are attributed to the varying beliefs of what constitutes emotional intelligence. Reuven Bar-On conceptualized a model with personality dimensions, emphasizing the co-dependence of the ability aspects of emotional intelligence with personality traits and their application to well-being. On the other hand, Daniel Goleman proposed a mixed model in terms of performance by combining an individual's abilities and personality implementing their corresponding effects in the workplace. 


\subsubsection{Mayer-Salovey-Caruso Ability Model}

Peter Salovey and John Mayer first coined the term "emotional intelligence" in 1990 and have continued to conduct research on the significance of the construct. They conceptualized ability based Emotional Intelligence Model which was based on the work of Gardner and his view on personal intelligence. Their model entails five broad areas: knowing one's own emotions, managing one's own emotions, self-motivation, recognizing emotions of others and handling relationships with others. Salovey and Mayer redefined emotional intelligence and proposed four branches; the first branch, emotional perception, is the ability to be self-aware of emotions and to express emotions and emotional needs accurately to others. It also includes the ability to distinguish between accurate and inaccurate or honest and tricky emotional expressions. The second branch, emotional assimilation, is the ability to distinguish among the different emotions one is feeling and to identify those that are influencing their thought processes by directing attention to important information. Just like Emotional mood swings change the individual's thinking pattern from optimistic to pessimistic, encouraging consideration of multiple points of view. Emotional states distinctively encourage specific problem-solving approaches such as happiness state facilitates inductive reasoning and creativity. The third branch, emotional understanding, is the ability to understand complex emotions and the ability to identify transitions from one emotion to the other such as the transition from anger to satisfaction or from anger to shame. Lastly, the fourth branch, emotion management, is the ability to stay open to both pleasant and unpleasant feelings, the ability to reflectively connect or detach from an emotion depending upon it being judged to be informative or utility and regulate emotions in both o ourselves and in others.

\subsubsection{Goleman's Competency Model}

Daniel Goleman popularized the concept of emotional intelligence in 1995, when he wrote the landmark book "Emotional Intelligence". He defined emotional intelligence as "abilities of being able to motivate one-self and survive in the face of frustrations; to control impulse and delay gratification; to manage one's moods and keep distress from swamping the ability to think; to empathize and to hope". Goleman's model outlines the four constructs of emotional intelligence. Self-awareness is the ability to identify one's emotions and recognize their impact while using gut feelings to guide decisions. Self-management, involves controlling one's emotions and impulses and thereby adapting to changing circumstances. Social awareness consists of the ability to sense, understand, and react to other's emotions while comprehending social networks. Finally, relationship management entails the ability to inspire, influence, and develop others while managing conflict. Goleman's model includes a set of emotional competencies within each construct of emotional intelligence, he opined that Emotional competencies are not innate talents, rather learned capabilities that must be worked on and developed to achieve outstanding performance.

\subsubsection{Bar-On's Mixed Model}

Bar-On introduced the term "Emotional Quotient" (EQ) in his doctoral dissertation as an analogue to Intelligent Quotient (IQ). His model of emotional intelligence can be viewed as a mixed intelligence, also consisting of cognitive ability and aspects of personality, health and well-being. It relates to the potential for performance and success and is considered process-oriented rather than outcome-oriented. He defined emotional intelligence as - an array of non-cognitive capabilities, competencies and skills that influence one's ability to succeed in coping with environmental demands and pressures. The definition encompasses a number of areas like emotional self-awareness, assertiveness, self-regard, self-actualization, independence, empathy, interpersonal relationship, social responsibility, problem solving, reality testing, flexibility, stress tolerance, impulse control, happiness and optimism. Insufficient emotional intelligence can mean a lack of success and the existence of emotional problems. Bar-On, considers that emotional intelligence and cognitive intelligence contribute equally to a person's general intelligence, which eventually indicates potential success in one's life.

\subsection{Emotional Intelligence and Gender}

Mayer, Caruso, \& Salovey (1999) suggest that women might have a slight advantage over men in the area of emotional intelligence. Bar-On (2000), however, suggests that no significant differences exist between males and females regarding overall emotional and social competence; but he does indicate some gender differences for a few factorial components of the construct.

Bar-On theorizes that females appear to be more aware of emotions, demonstrate more empathy, relate better interpersonally, and act more socially responsible than men. Men, on the other hand, appeared to be able to have better self-regard, cope better with stress, solve problems better, and be more independent, flexible, and optimistic than women. In general, when looking at the overall ratings of men and women, far more similarities exist than differences regarding their emotional intelligence. Thus, in terms of total emotional intelligence, no gender differences exist (1998).

In another study Bangash and Khan (2009) states that emotional intelligence does not respect the gender. The popular belief is that, women are not more emotionally intelligent than men. They are, however, emotionally intelligent in different ways. An analysis of emotional intelligence was found in thousands of men and women which showed that women, on average, are more aware of their emotions, show more empathy, and are more adept 
interpersonally. Men, on the other hand, are more self-confident, optimistic, and adaptable. It was found that men are also able to handle stress better than women.

In general, however, far more similarities exist than differences. Some men are empathetic as the most interpersonally sensible women are, while some women are just as able to withstand stress as the most emotionally resilient men. After taking into account overall ratings for men and women, the strengths and weaknesses average out, so it is a competition between both sexes.

Findings of studies reported by King (1999), Sutarso (1999), Wing and Love (2001) and Singh (2002) revealed that females have higher emotional intelligence than that of males. Since females tend to be more emotional and intimate in relationships as compared to males, so their emotional intelligence ought to be higher than that of males. Similar findings were reported in studies by Tapia (1999) and Dunn (2002). They observed that girls score higher with regard to empathy, social responsibilities and interpersonal relationships than boys.

A study based on integrative model of Petrides and Furnham's (2001) examined the relationships between trait EI and work related constructs. Gender specific perspective was adopted in order to take into account existing gender differences in work related variables as well as in perception of EI (Furnham, 1994; Petrides, Furnham \& Martin, 2004). Male and female data has been merged by many empirical studies even though there are reasons to believe that systematic differences in the ways in which the two genders experience the workplace and its demand exist (Roxburgh, 1996).

\subsection{Emotional Intelligence and Age}

Unlike IQ, which increases up to one's teen years, emotional intelligence seems always to continue to develop. As people learn from experiences, their emotional intelligence grows. Studies that have tracked people's emotional intelligence over the years indicate that people's competencies increase as they grow older (Goleman, 1998). BarOn (2000) found that older groups scored higher on the emotional quotient inventory scale score than younger groups. Individuals in their late forties and early fifties achieved the highest men score. The study suggests that emotional and social intelligence increases with age.

\subsection{Organizational Development}

Organization development (OD) is the process of improving organization effectiveness and/or individual employee effectiveness. The purposes are to increase the productivity, work satisfaction and profit for the client company. There are multiple definitions of OD. Richard Beckhard defines organization development as an effort (1) planned, (2) organization-wide), (3) managed from the top, (4) to increase organization effectiveness and health, through (5) planned interventions in the organizations processes using behavioral science knowledge" (Beckhard, 1969). Similarly OD is also defined as a systematic process for applying behavioral science principles and practices in organizations to increase individual and organizational effectiveness (French, 2008). So OD is improvement of the organization by developing its human resource through planned change efforts/interventions at all levels using human behavior approach.

The sets of structured /planned activities adopted by groups or individuals in an organization as a part of the organization development program are known as OD techniques or OD interventions. An intervention is a set of sequenced and planned actions or events intended to help the organization increases its effectiveness.

Sensitivity training is about making people understand about themselves and others reasonably which is done by developing in them social sensitivity and behavioral flexibility. Social sensitivity in one word is empathy. It is ability of an individual to sense what others feel and think from their own point of view. Behavioral sensitivity is ability to behave suitably in light of understanding.

Process consultation is the building of a helping relationship. Process consultation is the series of steps taken by a consultant to involve the person needing help in 1) the definition of the problem 2) the development of possible solutions and 3) the proposal for a final recommendation. In this way, the person takes an active role in the solving of his or her own conflict, rather than solely relying on the consultants' expert opinion.

It is a technique used for illustrating the quality of interpersonal communication- identifies a person's interpersonal style of communication. Process consultants use the model to help people process data about themselves in terms of how they see themselves and how others see them.

\section{RESEARCH METHODOLOGY}

\subsection{Research design}

Research design is the blueprint for fulfilling research objectives and answering research questions (John et al., 2007). In other words, it is a master plan specifying the methods and procedures for collecting and analyzing the needed information. The types of research design employed under this study were descriptive and explanatory research. The major purpose of descriptive research is description of the state of affairs, as it exists at present. Descriptive research design is adopted for this study and survey method is used for data collection. It is a factfinding enquiry of different nature. Descriptive research studies simply describe the current state of affairs as it is. 
The main characteristic of this design is that the researcher can only report what happened in the past and what is happening at present; he cannot predict accurately what will happen in future because he has no control over the variables.

\subsection{Sampling Design}

The population comprises of around 350 higher level managers and middle level executives at public sector organizations in Dire Dawa Administration, Ethiopia. The sample size selected for this study is 150. Simple random sampling technique is used for selecting the sample respondents. In this sampling technique, every unit of the population has an equal chance of being included in the sample size.

\subsection{Data Collection Method}

Primary data is collected directly from the sample respondents through a structured questionnaire using 5-points Likert scale that varies between not agree at all $=1$ and totally agree $=5$. According to Bryman and Bell, (2003) the self-completion questionnaire is very familiar method of business research, and the research instrument has to be especially easy to follow and its questions have to be particularly easy to answer. Meanwhile, whether to ask a question in an open or closed format is one of the most significant considerations for many researchers. Closed questions have some advantages: it is easy to process answers; it enhances the comparability of answers, and makes them easier to show the relationship between variables. It is better than open question for this research.

\subsection{Statistical Tools Used for Data Analysis}

The statistical tools used for data analysis were Weighted Average Method, Pearson's Correlation Co-efficient and Factor Analysis using SPSS V23.

\section{DATA ANALYSIS}

4.1 Descriptive Statistics

\begin{tabular}{|c|c|c|c|c|}
\hline EQ Factors & Description & $\mathbf{M}$ & STD & $\mathbf{N}$ \\
\hline Empathy & Understanding others' emotions & 4.41 & 1.6 & 150 \\
\hline Self-Awareness & Assessing the self & 4.13 & 1.41 & 150 \\
\hline Self-Regulation & Ability to control self & 3.77 & 1.04 & 150 \\
\hline Social Skills & Building bonds & 4.06 & 1.42 & 150 \\
\hline Motivation & Ability to accomplish the task & 4.54 & 1.63 & 150 \\
\hline Empathy & Understanding others' emotions & 4.41 & 1.6 & 150 \\
\hline OD Interventions & Description & $\mathbf{M}$ & STD & $\mathbf{N}$ \\
\hline Process Consultation & Problem defining and solution finding skills & 4.47 & 1.61 & 150 \\
\hline Team building & $\begin{array}{l}\text { Ability to build relationship and create rapport with } \\
\text { others }\end{array}$ & 2.96 & 1.18 & 150 \\
\hline $\begin{array}{l}\text { Organization } \\
\text { Building }\end{array}$ & Ability to cope with new advances in technology & 4.17 & 1.28 & 150 \\
\hline Sensitivity Training & Understanding of oneself and others & 4.04 & 1.22 & 150 \\
\hline Strategic Interventions & Ability to adapt with globalization & 4.06 & 1.33 & 150 \\
\hline HRM Interventions & Goal setting for the self (MBO) & 4.61 & 1.71 & 150 \\
\hline
\end{tabular}




\section{2: Multiple Correlations Analysis}

Null Hypothesis $\left(\mathbf{H}_{\mathbf{0}}\right)$ : EQ factors do not have any significant impact on Organizational Development using Process Consultation.

\begin{tabular}{|c|c|c|}
\hline EQ Factors & Correlations & $\begin{array}{l}\text { Process Consultation: Problem defining and } \\
\text { solution finding skills }\end{array}$ \\
\hline $\begin{array}{l}\text { Empathy: Understanding } \\
\text { others' emotions }\end{array}$ & $\begin{array}{l}\text { Pearson Correlation } \\
\text { Sig. (2 tailed) } \\
\text { Null Hypothesis (H0) }\end{array}$ & $\begin{array}{r}0.246 \\
0.040 \\
\text { Reject } \mathrm{Ho}_{0}\end{array}$ \\
\hline $\begin{array}{l}\text { Self-Awareness: Assessing } \\
\text { the self }\end{array}$ & $\begin{array}{l}\text { Pearson Correlation } \\
\text { Sig. ( } 2 \text { tailed) } \\
\text { Null Hypothesis (H0) }\end{array}$ & $\begin{array}{c}0.020 \\
0.871 \\
\text { Accept } \mathrm{H}_{0}\end{array}$ \\
\hline $\begin{array}{l}\text { Self-Regulation: Ability to } \\
\text { control self }\end{array}$ & $\begin{array}{l}\text { Pearson Correlation } \\
\text { Sig. ( } 2 \text { tailed) } \\
\text { Null Hypothesis (H0) }\end{array}$ & $\begin{array}{c}0.237 \\
0.048 \\
\text { Reject } \mathrm{H}_{0}\end{array}$ \\
\hline Social Skills: Building bonds & $\begin{array}{l}\text { Pearson Correlation } \\
\text { Sig. ( } 2 \text { tailed })\end{array}$ & $\begin{array}{l}-0.113 \\
0.353\end{array}$ \\
\hline $\begin{array}{l}\text { Motivation: Ability to } \\
\text { accomplish the task }\end{array}$ & $\begin{array}{l}\text { Null Hypothesis }(\mathrm{H} 0) \\
\text { Pearson Correlation } \\
\text { Sig. }(2 \text { tailed }) \\
\text { Null Hypothesis }(\mathrm{H} 0)\end{array}$ & $\begin{array}{c}\text { Accept } \mathrm{H}_{0} \\
0.339^{* *} \\
0.004 \\
\text { Reject } \mathrm{H}_{0}\end{array}$ \\
\hline
\end{tabular}

* Correlation is significant at 0.05 levels ( 2 tailed)

Decision: EQ factors such as Empathy, Self-regulation and Motivation have a significant impact on problem defining and solution finding skills of the employees. Hence, EQ factors have a significant impact on Organizational Development using Process Consultation.

\section{3: Multiple Correlation Analysis}

Null Hypothesis $\left(\mathbf{H}_{\mathbf{0}}\right)$ : EQ factors do not have any significant role in Organizational Development using HRM Interventions.

\begin{tabular}{|c|c|c|}
\hline EQ Factors & Correlations & $\begin{array}{l}\text { HRM Interventions: Goal Setting for } \\
\text { the Self (MBO) }\end{array}$ \\
\hline $\begin{array}{l}\text { Empathy: Understanding others' } \\
\text { emotions }\end{array}$ & $\begin{array}{l}\text { Pearson Correlation } \\
\text { Sig. (2 tailed) } \\
\text { Null Hypothesis }(\mathrm{H} 0)\end{array}$ & $\begin{array}{c}0.175 \\
0.148 \\
\text { Reject } \boldsymbol{H}_{0}\end{array}$ \\
\hline $\begin{array}{l}\text { Self-Awareness: Assessing the } \\
\text { self }\end{array}$ & $\begin{array}{l}\text { Pearson Correlation } \\
\text { Sig. ( } 2 \text { tailed) } \\
\text { Null Hypothesis }(\mathrm{H} 0)\end{array}$ & $\begin{array}{c}-0.046 \\
0.708 \\
\text { Accept } \mathrm{H}_{0}\end{array}$ \\
\hline $\begin{array}{l}\text { Self-Regulation: Ability to } \\
\text { control self }\end{array}$ & $\begin{array}{l}\text { Pearson Correlation } \\
\text { Sig. (2 tailed) } \\
\text { Null Hypothesis (H0) }\end{array}$ & $\begin{array}{c}-0.006 \\
0.960 \\
\text { Accept } \mathrm{H}_{0} 0\end{array}$ \\
\hline Social Skills: Building bonds & $\begin{array}{l}\text { Pearson Correlation } \\
\text { Sig. ( } 2 \text { tailed) } \\
\text { Null Hypothesis }(\mathrm{H} 0)\end{array}$ & $\begin{array}{c}-0.012 \\
0.921 \\
\text { Accept } \boldsymbol{H}_{0}\end{array}$ \\
\hline $\begin{array}{l}\text { Motivation: Ability to } \\
\text { accomplish the task }\end{array}$ & $\begin{array}{l}\text { Pearson Correlation } \\
\text { Sig. }(2 \text { tailed) } \\
\text { Null Hypothesis }(\mathrm{H} 0)\end{array}$ & $\begin{array}{c}0.223 \\
0.064 \\
\text { Reject } \mathrm{H}_{0}\end{array}$ \\
\hline
\end{tabular}

* Correlation is significant at 0.05 levels (2 tailed)

Decision: EQ factors Empathy and Motivation have a significant role in employee goal setting. However, other EQ factors such as self-awareness, self-regulation and social skills do not have any significant role in employee goal setting. Thus, EQ factors play only a limited role in Organizational Development using HRM Interventions. 


\section{4: Multiple Correlation Analysis}

Null Hypothesis $\left(\mathbf{H}_{\mathbf{0}}\right)$ : EQ factors do not have any significant impact on Organizational Development using Team Building Technique.

\begin{tabular}{|c|c|c|}
\hline EQ Factors & Correlations & $\begin{array}{l}\text { Team Building: Ability to build relationship and } \\
\text { create good rapport with others }\end{array}$ \\
\hline Empathy: & Pearson Correlation & 0.004 \\
\hline \multirow{2}{*}{$\begin{array}{l}\text { Understanding others' } \\
\text { emotions }\end{array}$} & Sig. (2 tailed) & 0.974 \\
\hline & Null Hypothesis (H0) & Accept $\mathrm{H}_{0}$ \\
\hline \multirow{2}{*}{$\begin{array}{l}\text { Self-Awareness: } \\
\text { Assessing the self }\end{array}$} & Pearson Correlation & 0.034 \\
\hline & Sig. (2 tailed) & 0.778 \\
\hline \multirow{4}{*}{$\begin{array}{l}\text { Self-Regulation: } \\
\text { to control self }\end{array}$} & Null Hypothesis (H0) & Accept $\mathrm{H}_{0}$ \\
\hline & Pearson Correlation & -0.012 \\
\hline & Sig. (2 tailed) & 0.922 \\
\hline & Null Hypothesis (H0) & Accept $\mathrm{H}_{0}$ \\
\hline \multirow{3}{*}{$\begin{array}{l}\text { Social Skills: Building } \\
\text { bonds }\end{array}$} & Pearson Correlation & -0.011 \\
\hline & Sig. (2 tailed) & 0.931 \\
\hline & Null Hypothesis (H0) & Accept $\mathrm{H}_{0}$ \\
\hline \multirow{3}{*}{$\begin{array}{l}\text { Motivation: Ability to } \\
\text { accomplish the task }\end{array}$} & Pearson Correlation & 0.153 \\
\hline & Sig. (2 tailed) & 0.206 \\
\hline & Null Hypothesis (H0) & Accept $\mathrm{H}_{0}$ \\
\hline
\end{tabular}

* Correlation is significant at 0.05 levels (2 tailed)

Decision: No EQ factors have any significant impact on Organizational Development using Team Building Technique.

\section{5: Multiple Correlation Analysis}

Null Hypothesis $\left(\mathbf{H}_{\mathbf{0}}\right)$ : EQ factors do not have any significant impact on Organizational Development using Organizational Process Building.

\begin{tabular}{|c|c|c|}
\hline EQ Factors & Correlations & $\begin{array}{l}\text { Organization Process Building: Ability to cope } \\
\text { with new advances in technology }\end{array}$ \\
\hline $\begin{array}{l}\text { Empathy: Understanding } \\
\text { others' emotions }\end{array}$ & $\begin{array}{l}\text { Pearson Correlation } \\
\text { Sig. (2 tailed) } \\
\text { Null Hypothesis }(\mathrm{H} 0)\end{array}$ & $\begin{array}{c}0.001 \\
0.993 \\
\text { Accept } \mathrm{H}_{0}\end{array}$ \\
\hline Self-Awareness: & Pearson Correlation & 0.182 \\
\hline Assessing the self & $\begin{array}{l}\text { Sig. ( } 2 \text { tailed) } \\
\text { Null Hypothesis }(\mathrm{H} 0)\end{array}$ & $\begin{array}{c}0.131 \\
\text { Reject } \mathrm{Ho}_{0}\end{array}$ \\
\hline $\begin{array}{l}\text { Self-Regulation: } \\
\text { Ability to control self }\end{array}$ & $\begin{array}{l}\text { Pearson Correlation } \\
\text { Sig. }(2 \text { tailed) } \\
\text { Null Hypothesis }(\mathrm{H} 0)\end{array}$ & $\begin{array}{c}-0.136 \\
0.260 \\
\text { Accept } \mathrm{H}_{0}\end{array}$ \\
\hline $\begin{array}{l}\text { Social Skills: Building } \\
\text { bonds }\end{array}$ & $\begin{array}{l}\text { Pearson Correlation } \\
\text { Sig. }(2 \text { tailed) } \\
\text { Null Hypothesis }(\mathrm{H} 0)\end{array}$ & $\begin{array}{c}0.009 \\
0.939 \\
\text { Accept } \mathrm{H}_{0}\end{array}$ \\
\hline $\begin{array}{l}\text { Motivation: Ability to } \\
\text { accomplish the task }\end{array}$ & $\begin{array}{l}\text { Pearson Correlation } \\
\text { Sig. }(2 \text { tailed }) \\
\text { Null Hypothesis }(\mathrm{H} 0)\end{array}$ & $\begin{array}{c}0.026 \\
0.830 \\
\text { Accept } \mathrm{H}_{0}\end{array}$ \\
\hline
\end{tabular}

* Correlation is significant at 0.05 levels (2 tailed)

Decision: Only Self-Awareness has a significant impact on employees' ability to cope with new advances in technology. No other EQ factors have any significant impact on their ability to cope with new advances in technology. Thus, EQ factors have only a limited impact on Organizational Development using Organizational Process Building. 


\section{6: Multiple Correlation Analysis}

Null Hypothesis $\left(\mathbf{H}_{\mathbf{0}}\right)$ : EQ factors do not have any significant impact on Organizational Development using Sensitivity Training.

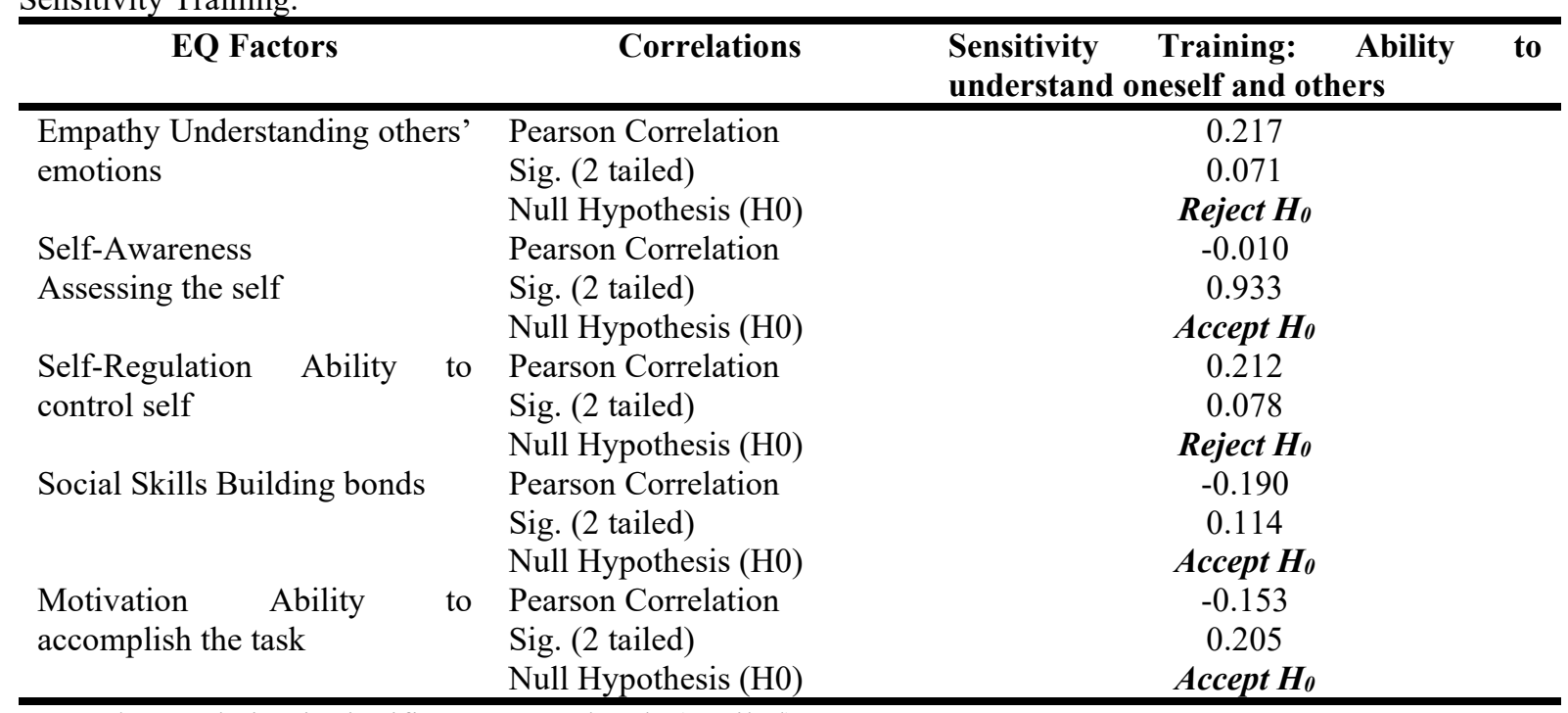

\footnotetext{
* Correlation is significant at 0.05 levels (2 tailed)
}

Decision: EQ factors Empathy and Self-Regulation have a significant impact on employees' ability to understand themselves and others. However, other EQ factors such as Self-Awareness, Social Skills and Motivation do not have any significant impact on their ability to understand themselves and others. Thus, EQ factors have only a limited impact on Organizational Development using Sensitivity Training.

\section{7: Multiple Correlation Analysis}

Null Hypothesis $\left(\mathbf{H}_{0}\right)$ : EQ factors do not have any significant impact on Organizational Development using Strategic Interventions.

\begin{tabular}{|c|c|c|}
\hline EQ Factors & Correlations & $\begin{array}{l}\text { Strategic Interventions: Ability to adapt with } \\
\text { globalization }\end{array}$ \\
\hline Empathy: & Pearson Correlation & -0.229 \\
\hline \multirow{2}{*}{$\begin{array}{l}\text { Understanding others' } \\
\text { emotions }\end{array}$} & Sig. (2 tailed) & 0.057 \\
\hline & Null Hypothesis (H0) & Accept $\mathrm{H}_{0}$ \\
\hline Self-Awareness: & Pearson Correlation & 0.220 \\
\hline \multirow[t]{2}{*}{ Assessing the self } & Sig. (2 tailed) & 0.068 \\
\hline & Null Hypothesis (H0) & Reject $\mathrm{Ho}_{0}$ \\
\hline Self-Regulation: & Pearson Correlation & 0.174 \\
\hline \multirow{2}{*}{ Ability to control self } & Sig. (2 tailed) & 0.149 \\
\hline & Null Hypothesis (H0) & Reject $\mathrm{H}_{0}$ \\
\hline \multirow{3}{*}{$\begin{array}{l}\text { Social } \\
\text { bonds }\end{array}$} & Pearson Correlation & -0.011 \\
\hline & Sig. (2 tailed) & 0.930 \\
\hline & Null Hypothesis (H0) & Accept $\mathrm{H}_{0}$ \\
\hline \multirow{3}{*}{$\begin{array}{l}\text { Motivation } \\
\text { Ability to accomplish the } \\
\text { task }\end{array}$} & Pearson Correlation & 0.028 \\
\hline & Sig. (2 tailed) & 0.819 \\
\hline & Null Hypothesis (H0) & Accept $\mathrm{H}_{0}$ \\
\hline
\end{tabular}

\footnotetext{
* Correlation is significant at 0.05 levels (2 tailed)
}

Decision: EQ factors such as Self-Awareness, Self-Regulation and Motivation have a significant impact on employees' ability to adapt with globalization. However, Empathy and Social Skills do not have any significant impact on employees' ability to adapt with globalization. Thus, EQ factors have a significant impact on Organizational Development using Strategic Interventions. 


\section{8: Factor Analysis}

Aim: To obtain two new factors from the actual factors of Emotional Intelligence and OD Interventions based on educational qualification, experience and gender of the employees.

Rotated Component Matrix

\begin{tabular}{|c|c|c|c|c|}
\hline \multirow[t]{2}{*}{ No } & \multirow[t]{2}{*}{ Description } & \multicolumn{3}{|c|}{ Component } \\
\hline & & 1 & 2 & 3 \\
\hline 1. & Process Consultation: Problem solving and solution finding skills & 0.596 & & \\
\hline 2. & Sensitivity Training: Understanding oneself and others & 0.590 & & \\
\hline 3. & Motivation: Ability to accomplish the task & 0.563 & & \\
\hline 4. & Self-Regulation: Ability to control self & 0.523 & & \\
\hline 5. & $\begin{array}{l}\text { Team Building: Ability to build relationships and create good rapport with } \\
\text { others }\end{array}$ & 0.518 & & \\
\hline 6. & $\begin{array}{l}\text { Social Skills: Building bonds } \\
\text { Based on Educational Qualification of the Employees }\end{array}$ & 0.489 & & \\
\hline 1. & Empathy: Understanding others' emotions & & 0.579 & \\
\hline 2. & Process Consultation: Problem solving and solution finding skills & & 0.513 & \\
\hline 3. & $\begin{array}{l}\text { Human Resources Management Interventions: Goal setting for the self } \\
\text { (MBO) }\end{array}$ & & -.426 & \\
\hline 4. & $\begin{array}{l}\text { Social Skills: Building bonds } \\
\qquad \text { Based on Experience of the Employees }\end{array}$ & & -.413 & \\
\hline 1. & Self-Awareness: Assessing the self & & & 0.698 \\
\hline 2. & Self-regulation: Ability to control self & & & 0.523 \\
\hline 3. & $\begin{array}{l}\text { Organization process building: Ability to cope with new advances in } \\
\text { Technology }\end{array}$ & & & -.499 \\
\hline $\begin{array}{l}\mathbf{E x} \\
\text { No }\end{array}$ & $\begin{array}{l}\text { Based on Gender of the Employees } \\
\text { ction Method: Principal Component Analysis. Rotation Method: } \\
\text { alization. }\end{array}$ & Varimax & with & Kaiser \\
\hline
\end{tabular}

Inferences':

* The EQ factors such as Motivation, Self-Regulation and Social Skills are highly correlated with OD techniques like Process Consultation and Team Building and hence they are grouped together in the first factor of the Rotated Component Matrix. Thus, the obtained first factor is given the name "Skills for a Better Manager".

* The EQ factor Empathy is highly correlated with OD technique Process Consultation and hence they are grouped together in the second factor of the Rotated Component Matrix. The remaining factors like HRM interventions and Social Skills have negative correlation. Hence, the obtained second factor can be named "Skills for Solution Finder".

* The other EQ factors do not have any correlation with the other OD interventions. Hence, no new factor emerges.

Decision: Hence the obtained factors are: First factor: "Skills for a Better Manager" are Self-regulation, Social skills and Ability to accomplish the task. Second Factor: "Skills for Solution Finder" is Empathy.

\section{SUMMARIES, CONCLUSIONS AND RECOMMENDATIONS}

\section{1: Summary of findings}

Respondents in the age group of 45-55 years have higher empathy level than others.

$\$$ Respondents who are less than 25 years of age have higher level of social skills than others.

$\$$ Respondents in the age group of 45-55 years have higher level of self-awareness than others.

* Respondents in the age group of 25-35 years have higher level of self-regulation than others.

* Respondents who are less than 25 years of age have a higher level of motivation than others.

* Male respondents possess higher level of empathy and social skills than female respondents.

\$ Female respondents possess higher level of self-awareness, self-regulation and motivation than male respondents.

* Respondents with professional qualifications possess higher level of EQ than others.

* Respondents with 6-10 years of experience possess better problem solving skill than others.

* Respondents who possess less than 5 years of experience have greater team building ability than others.

* Respondents having 16-20 years of experience possess greater ability to cope with new advances in technology and organizational change than others

* EQ factors such as Empathy, Self-regulation and Motivation have a significant impact on problem defining and solution finding skills of the employees. 
$\$$ EQ factors Empathy and Motivation have a significant role in employee goal setting.

+ No EQ factors have any significant impact on Organizational Development using Team Building Technique.

* Only Self-Awareness has a significant impact employees' ability to cope with new advances in technology. No other EQ factors have any significant impact in this regard.

* EQ factors Empathy and Self-Regulation have a significant impact on employees' ability to understand themselves and others,

* EQ factors such as Self-Awareness, Self-Regulation and Motivation have a significant impact on employees' ability to adapt with globalization.

* Skills for a Better Manager" are Self-regulation, Social skills and Ability to accomplish the task. "Skills for Solution Finder" is Empathy.

\section{2: Suggestions and recommendations}

+ From the research findings, it has been found that though there is a positive correlation between some EQ factors and OD interventions, they have only a moderate impact on Organizational Development. Hence, it is suggested that training programs can be organized for increasing the problem solving, decisionmaking, team building and task accomplishment skills of the employees. This will help the organization increase the emotional intelligence of the work force thereby enhancing their productivity.

+ Since respondents having higher educational qualification possess higher level of Emotional Intelligence Quotient than others, the organizations could encourage and motivate their employees to attain higher professional qualifications. This can be done by sponsoring the employees to obtain higher qualifications in the fields of engineering, technology and management through weekend and part-time courses.

* From the study, it is observed that male respondents have lower level of self-awareness, self-regulation, and motivation than female respondents, whereas female respondents have lower level of empathy and social skills than male respondents. Hence, they can be provided sensitivity training in order to enhance their lacking skills.

* Not all EQ factors other than self-awareness have any significant impact on employees' ability to cope with new advances in technology. Hence, the organizations can facilitate their production and maintenance employees to adapt themselves with new technology by providing them on the job training and conducting workshops.

\section{3: Directions for future research}

This research analyzes a few of the EQ factors and OD interventional strategies. Developing the Emotional Intelligence Quotient of employees for organizational development is a continuous process and there are many other EQ factors required for an employee to contribute more to organizational development and to lead an ideal life. These factors can be identified and their influence on Organizational Development can be analyzed in future research.

\section{REFERENCES}

- Anthony C. Mersino, “Emotional Intelligence for Project Managers: The People Skills You Need to Achieve Outstanding Results”, American Management Association, 2013

- Bar-On, R. (1997), Bar-On Emotional Quotient Inventory: User's Manual, Multi-Health Systems, New York, NY.

- Bar-On, R. (2000). Emotional and social intelligence: Insights from the Emotional Quotient Inventory (EQ-I) In R. Bar-on \& J.D.A. Parker (Eds.), Handbook of Emotional Intelligence (pp. 363-388). San Francisco: Jossey-Bass.

- $\quad$ Beckhard, R., (1969), Organizational Development: Strategies and Models, Reading Mass, Addison-Wesley.

- Brackett M. A. \&Salovey .P. (2006), "Measuring Emotional Intelligence with the Mayer-Salovey-Caruso Emotional Intelligence Test (MSCEIT). Psicothema” Vol. 18.

- Carmeli A. \& Josman Z, (2006) "The Relationship among Emotional Intelligence, Task Performance and Organizational Citizenship Behaviors ", Human Performance, 19(4), 403-419,.

- Carter McNamara, (nd) "Field Guide to Consulting and Organizational Development", Authenticity Consulting, LLC

- Daniel Goleman, (2005) “Emotional Intelligence: Why It Can Matter More Than IQ”, September 27,

- Daus C.S \& Ashkanasy, N. M, (2005) "The case for the ability-based model of emotional intelligence in organizational behavior', Journal of Organizational Behavior, 26(4), 453-466

- Devi, S. Anitha, (2012) "Assessing Emotional Intelligence: Academic Performance \& Overall Personality Development', Indian Journal of Industrial Relations, Vol. 48, No. 2, October 
- Dunn, P. (2002) The impact of starting a new venture on the entrepreneur and their family: Expectations, reality, and willingness to start again. 2002 Annual Conf

- Fisher, C. D \& Ashkanasy, N. M, (2000) "The emerging role of emotions in work life: An introduction", Journal of Organizational Behavior, 21(Spec Issue), 123-129.

- French, W. L. et al, (2008), Organization Development: Behavioral Science Interventions for Organization Improvement", Dorling Kindersley (India) Pvt. Ltd., India.

- Fullan, M. (2001). Leading in a culture of change. San Francisco, CA: Josey-Bass Publishers.

- Gerald Matthews, Moshe Zeidner and Richard D. Roberts (2007) "The Science of Emotional IntelligenceKnowns and Unknowns', Oxford University press,

- Goleman, D. (1995) Emotional Intelligence. New York: Bantam.

- Goleman, D. (1998) Working with emotional intelligence. New York: Bantam Books

- Goleman, D. (2001). "An EI-based theory of performance", in Cherniss, C. and Goleman, D. (Eds), The Emotionally Intelligent Workplace, Jossey-Bass, San Francisco, CA, pp. 27-44.

- Goleman, D., Boyatzis, R. and McKee, A. (2002). "The emotional reality of teams", Journal of Organizational Excellence, Winter, pp. 55-65.

- Jordan, P. \& Troth, A., (2011), "Emotional Intelligence and leader member exchange: The relationship with employee turnover intentions and job satisfaction. Leadership \& Organization", Development Journal, Vol 32 .

- Kavita Singh, (2009) “Organisation Change and Development”' Excel Books India, Jan 1,

- $\quad$ King, M. (1999). Measurements of differences in emotional intelligence of preserves educational leadership students and practicing administrators as measured by the multifactor emotional intelligence Scale. Dissert. Abst. Int. 60(3): 606.

- Law, K., Wong, C., Huang, G., \& Li, X. (2008), “The effects of emotional intelligence on job performance and life satisfaction for the research and development scientists in China", Asia Pacific Journal of Management, Vol 25

- $\quad$ Law, K.S., Wong, C.S., \& Song L.J., (2004)The construct and criterion validity of emotional intelligence and its potential utility for management studies Journal of Applied Psychology, Vol.89,. Pp 483 - 496

- Mayer, J.D., and Salovey, P. (1999). Emotional intelligence meets traditional standards for intelligence, Intelligence, 27,267-298.

- Momeni, N. (2009) “The Relation between Managers' emotional intelligence and the organizational climate they create', Public Personnel Management, 38(2), 35-48.

- Naeem, H, Saif, MI \& Khalil, W (2008), "Emotional Intelligence And Its Impact On Service Quality Empirical Evidence from the Pakistani Banking Sector", International Business \& Economics Research Journal, vol. 7.

- O'Boyle, E. H., Jr., R. H. Humphrey, et al., (2011) "The relation between emotional intelligence and job performance: A meta-analysis', Journal of Organizational Behavior, 32(5), 788-818.

- Palmer, B., Walls, M., Burgess, Z. and Stough, C. (2001) Emotional intelligence and effective leadership, Leadership \& Organization Development Journal 22(1), pp.5-10

- Petrides, K.V. \& Furnham, A. (2001). Trait emotional intelligence: Psychometric investigation with reference to established trait taxonomies. European Journal of Personality, 15, 425- 448.

- $\quad$ Petrides, K.V., Frederickson, N., \& Furnham, A. (2004). The role of trait emotional intelligence in academic performance and deviant behavior at school. Personality and Individual Differences, 36, 277-293.

- Petrides, K.V. \& Furnham, A. (2006). The role of trait emotional intelligence in a gender specific model of organizational variables. Journal of Applied Social Psychology, 36, 552-569.

- $\quad$ Praeger, Adele B. Lynn, (2004) "The EQ Difference: A Powerful Program for Putting Emotional Intelligence to Work', American Management Association,

- Prati, L.M., C. Douglas, et al., (2003) Emotional intelligence, leadership effectiveness, and team outcomes International Journal of Organizational Analysis 11(1): 21-40

- Salovey, P. \& Grewal, D., (2005) "The Science of Emotional Intelligence: Current Directions in Psychological Science” Vol. 14.

- Seymour Epstein, (1998) "Constructive Thinking: The Key to Emotional Intelligence”

- Singh, S. K, (2007) "Role of Emotional Intelligence in Organizational Learning: An Empirical Study", Singapore Management Review, 29(2), 55-74.

- Singh, D.(2002). Emotional intelligence at work: A professional Guide. New Delhi: Sage Publications.

- Sutarso, P.( 1999). Gender differences on the emotional intelligence inventory (EQI). Dissert. Abst.Int.

- Sy, T., Tram, S., \& O'Hara, L. (2006) "Relation of employee and manager emotional intelligence to job satisfaction and performance." Journal of Vocational Behavior, the International Journal of Management Vol 
7 Issue 1 (January, 2018).

- Tapia, M.L. (1999). A study of the relationships of the emotional intelligence inventory (intelligence tests). Dissert. Abst. Int.

- Wing, E. and G.D. Love. (2001) Elective Affinities and Uninvited Agonies: Mapping Emotions Significant others onto health. Emotions, Social Relationships and Health Series in Affective Sci. New York: Oxford Univ. Press.

- Wong, C., Law, K., \& Wong, P. (2004), "Development and validation of a forced choice emotional Intelligence measure for Chinese respondents in Hong Kong.", Asia Pacific Journal of Management, Vol 21

- Zhou, J., \& Shalley, C. E. (2003). Research on employee creativity: A critical review and directions for future research. In J. Martocchio (Ed.), Research in personnel and human resources management, vol. 22: 165-217. Greenwich, CT: JAI Press.
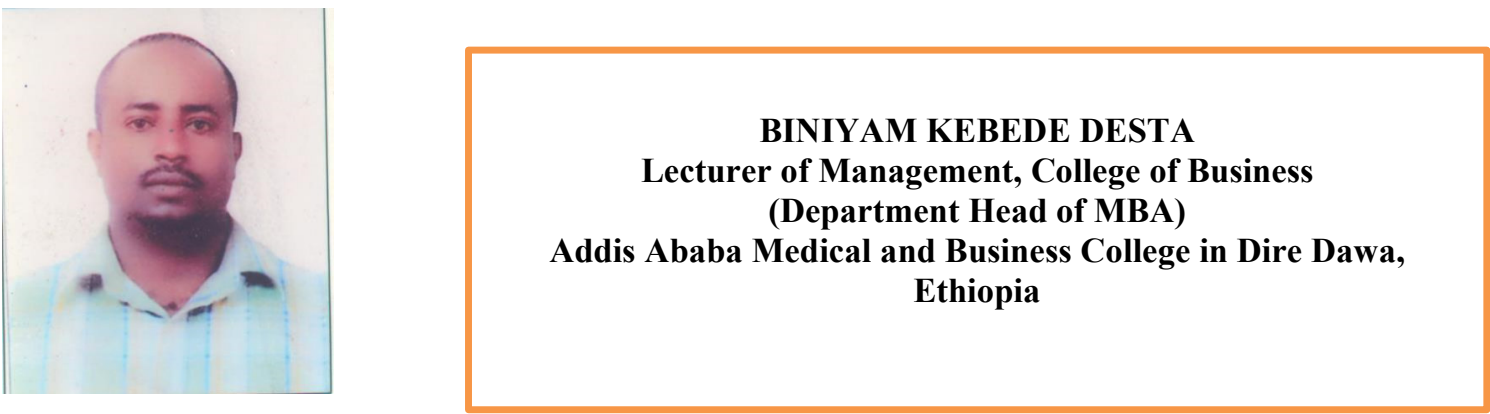